\title{
MANAJEMEN EKONOMI SYARIAH DALAM FUNGSI-FUNGSI BISNIS ISLAM
}

\author{
Nani Feliyani \\ Institut Agama Islam Negeri Surakarta \\ e-mail: nanifeliyani12@gmail.com
}

\begin{abstract}
In sharia business, management is used as a basic element that is attached to business processes that will be used as a reference by managers in carrying out activities to achieve goals. The management urgency in business is designed to cover four functions, namely production, personnel, marketing and finance. Business in Islam also aims to achieve four main things: targets results, material and non-material benefits, sustainability of growth, and blessings. This research is qualitative library research using sources from various references conducted descriptively and analytically. The findings suggest that in its application, business management cannot be separated from the beliefs and values underliying it, which must be in accordance with the view of life and Islam.
\end{abstract}

\section{Keywords: management; Islamic business; transactions}

\section{Pendahuluan}

Bisnis adalah bagian dari aktivitas manusia dalam setiap hari yang tidak dapat dilepaskan kaitannya dalam memenuhi unsur hajat primer, sekunder dan tersier. Dalam memenuhi kebutuhan tersebut, manusia dituntut agar selalu produktif dalam menciptakan halhal baru agar kelak mampu membentuk tatanan yang perspektif dalam aktivitas memenuhi hajat sesuai dengan situasi dan kondisinya.

Manajemen pada dasarnya merupakan suatu proses pengambilan keputusan yang berkaitan dengan perencanan, pengorganisasian, pengarahan, dan pengendaliam yang dilakukan untuk mencapai tujuan organisasi. Sedangkan manajemen ekonomi Islam (syariah) sejak tahun 1980-an pembahasannya kebanyakan masih secara umum yang dilengkapi dengan ayat-ayat al-Quran atau hadis-hadis sebagai pendukung manajemen konvensional. Manajemen syariah adalah seni mengelola semua sumber daya yang dimiliki dengan metode syariah yang telah tercantum dalam al-Quran dan hadis. Konsep syariah yang diambil dari al-Quran dijadikan sebagai dasar hukum utama dan dijadikan pandangan hidup dalam manajemen ekonomi syariah.

Islam mengatur hubungan yang kuat antara akhlak, akidah, ibadah dan muamalah. Aspek muamalah lah yang merupakan aturan main bagi manusia dalam menjalankan kehidupan sosial sekaligus menjadi dasar untuk membangun sistem perekonomian yang sesuai dengan nilai-nilai Islam. Ajaran muamalah akan menahan manusia dari menghalalkan segala cara untuk mencari rizki. Muamalah mengajarkan manusia untuk mencari rizki secara halal dan baik.

Manajemen dan bisnis merupakan suatu konsep yang terdapat dalam ekonomi. Kedua hal tersebut saling berkaitan antara satu sama lain. Dengan adanya konsep manajemen syariah kemudian muncul pertanyaan bagaimana caranya agar konsep manajemen tersebut dapat di 
implementasikan dalam dunia bisnis. Bisnis Islam memiliki empat fungsi, yaitu fungsi produksi, personalia, pemasaran, dan keuangan. Dalam pelaksanaan implementasi tersebut tidak boleh lepas dari keyakinan dan nilai yang mendasarinya. Manajemen harus sesuai dengan pandangan hidup dan Islam. Al-Quran sendiri telah memberikan petunjuk yang dapat digunakan sebagai dasar membangun ilmu manajemen bisnis Islam.

\section{Kerangka Pemahaman Manajemen Ekonomi Syariah}

Manajemen ekonomi syariah dapat dipahami dengan menggunakan kerangka kerja konseptual Islam. Kerangka tersebut terdiri dari:

1. Pandangan hidup

Jika kita melihat tujuan akhir dari manajemen ekonomi syariah adalah pencapaian kebahagiaan dunia dan akhirat, maka prinsip manajemen ekonomi syariah tentunya tidak memisahkan dunia dan akhirat. Dalam al-Quran dan hadis dapat ditemukan beberapa prinsip-prinsip manajemen ekonomi syariah tersebut, yaitu tauhid, ibadah, amanah, tanggung jawab, hikmah, adil, ihsān, tolong menolong, dan halalan tayyiban. Prinsipprinsip tersebut merupakan sebuah kesatuan terpadu yang dijadikan sebagai pedoman melakukan aktivitas bisnis Islam. Jika hal tersebut diimplementasikan dalam dunia bisnis, maka dapat merealisasikan tujuan dari syariat Islam, yaitu maqāșid shar'iyyah yang artinya memberikan manfaat maslahat kepada umat manusia. Perlu dipahami bahwa manajemen ekonomi syariah tidak dapat dipisahkan dengan tujuan syariat Islam, yakni memenuhi kebutuhan manusia, baik kebutuan primer, sekunder dan tersier.

Pandangan hidup mencerminkan keberadaan, identitas dan implikasinya guna mewujudkan esensi dan efektivitas dalam pekerjaan manajemen. Untuk merealisasikan tujuan diperlukan faktor-faktor penunjang, baik yang menyangkut individu maupun kepentingan masyarakat umum sehingga terdapat keseimbangan dalam manajemen. Dan untuk mendapatkan efektivitas setinggi-tingginya diperlukan pengorbanan semaksimal mungkin sehingga tujuan manajemen tersebut dapat terpenuhi dengan baik.

Pandangan hidup manajemen ekonomi syariah sebagai salah satu sistem ekonomi yang dipakai di dunia ini di mana tidak terlepas dari sistem ekonomi seperti kapitalisme. Mengejar keuntungan dalam sistem ekonomi kapitalis menjadi ciri utama sistem ini. Akan tetapi dalam ekonomi syariah hal tersebut juga dianjurkan, namun harus diperhatikan bahwa harus keseimbangam dengan kemanfaatannya. Dengan kata lain, sebisa mungkin tidak ada pihak yang merasa dirugikan. Selain itu kehalalan dan kebaikan (halalan tayyiban) dalam setiap aspek produksi, transaksi, dan konsumsi menjadi syarat dalam ekonomi syariah.

2. Ontologi

Ontologi adalah bagian dari filsafat yang paling umum atau merupakan bagian dari metafisika yang merupakan salah satu bab dari filsafat. Obyek telaah ontologi adalah yang ada tidak terikat pada satu perwujudan tertentu. Ontologi membahas tentang yang ada secara universal, yaitu berusaha mencari inti yang dimuat dari setiap kenyataan yang meliputi segala realitas dalam semua bentuknya. ${ }^{1}$

Secara ontology, ilmu ekonomi Islam berdasarkan dua ilmu, yaitu ilmu ekonomi

\footnotetext{
${ }^{1}$ Inu Kencana Syafi'i, Pengantar Ilmu Filsafat (Bandung: Refika Aditama, 2004), 9.
} 
murni dan ilmu fikih muamalah. Dalam operasionalnya, ilmu ekonomi Islam akan selalu bersumber dari kedua disiplin ilmu tersebut. Persoalan ontologis tersebut memadukan antara pemikiran sekular ilmu ekonomi dengan pemikiran sakral yang terdapat dalam fikih muamalah.

Dengan munculnya sumber ilmu pengetahuan ini menyebabkan perbedaan persepsi terhadap masalah-masalah ekonomi yang ada dalam aktivitas manusia sehari-hari. Sebagai contoh, ilmu ekonomi akan mengahalalkan sistem ekonomi liberal, kapitalis, dan komunis selama hal tersebut dapat memenuhi kebutuhan manusia. Tetapi sebaliknya, fikih muamalah belum tentu dapat menerima ketiga sistem ekonomi tersebut, dikarenakan fikih muamalah bersumber dan masih membutuhkan legislasi dari al-Quran dan hadis.

Ilmu ekonomi bersumber dari pemikiran manusia dengan mengacu tiga teori kebenaran, yaitu teori koherensi (kesesuaian dengan teori yang sudah ada), teori korespondensi (kesesuaian dengan fenomena yang ada), dan teori pragmatisme (kesesuaian dengan kegunaannya). Sedangkan fikih muamalah bersumber dari wahyu yang berasal dari Allah di mana transaksi ekonomi akan dipandang benar apabila tidak terdapat larangan dalam wahyu. Berdasarkan perbedaan sumber pengetahuan dan teori kebenaran yang digunakan maka tentu saja sulit untuk memadukan antara ilmu ekonomi dan fikih muamalah.

3. Epistomologi

Terjadi perdebatan filosofis di sekitar pengetahuan manusia yang menduduki pusat permasalahan di dalam filsafat, terutama filsafat modern. Pengetahuan manusia merupakan titik tolak kemajuan filsafat untuk membina filsafat yang kokoh tentang semesta (universe) dan dunia. Maka sumber-sumber pemikiran manusia, kriteria-kriteria, dan nilai-nilainya tidak ditetapkan, tidaklah mungkin melakukan studi apapun, bagaimanapun bentuknya. $^{2}$

Kajian epistomologi membahas tentang bagaimana proses mendapatkan ilmu pengetahuan, hal-hal apakah yang harus diperhatikan agar mendapatkan pengetahuan yang benar, apa yang disebut kebenaran dan apa kriterianya. Sedangkan objek epistomologi adalah mempertanyakan bagaimana sesuatu itu datang, bagaimana kita mengetahuinya, bagaimana kita membedakan dengan lainnya, jadi berkenan dengan situasi dan kondisi ruang waktu mengenai sesuatu hal. ${ }^{3}$

Secara epsitomologis, cara kerja ilmu ekonomi melalui pengamatan (empirisme) terhadap gejala sosial masyarakat dalam memenuhi kebutuhannya di mana menggunakan penalaran yang bersifat kuantitatif melalui pengamatan yang dilakukan dengan melakukan generalisasi untuk mengambil kesimpulan yang bersifat universal atau umum. Sedangkan cara kerja fikih muamalah berdasarkan penelusuran langsung terhadap alQuran dan hadis oleh para mujtahid dengan menggunakan penalaran yang bersifat kualitatif, yaitu penalaran yang bersifat untuk mendapatkan kesimpulan yang baik dan benar.

Salah satu contoh yang dapat dikemukakan dalam kasus ini adalah kaidah uṣul al-

\footnotetext{
${ }^{2}$ Muhammad Baqir Ash-shadr, Falsafatuna Terhadap Berbagai Aturan Filsafat Dunia (Bandung: Mizan, 1999), 5 .

${ }^{3}$ Inu Kencana Syafi'i, Pengantar Ilmu Filsafat, 10.
} 
fiqh yang berbunyi al-aṣl fí al-ashyā' al-ibạhah illä dalla al-dalil 'alä taḥrimih, yaitu asal segala sesuatu adalah dibolehkan, kecuali jika ada dalil yang mengharamkannya. Jika diterapkan dalam ilmu ekonomi, maka seluruh transaksi bisnis pada dasarnya diperbolehkan jika tidak ada nas yang mengharamkannya. Pelarangan terhadap praktik bunga dan riba dalam perbankan konvensional hanya disebabkan beberapa nas yang menharamkannya, misalnya Q.S. al-Baqarah ayat 275.

4. Metodologi

Metodologi dalam ekonomi syariah dapat dilakukan dengan dua cara, yaitu melalui islamisasi ilmu dan kembali kepada falsafah ilmu Islam. Kedua pendekatan ini melibatkan atau memerlukan sumber-sumber fikih. Islamisasi yang dimaksud adalah memasukkan nilai-nilai agama dan mengeluarkan nilai yang bertentangan dengan agama ke dalam analisis konvensional yang telah ada. Dalam proses islamisasi ini terjadi dua proses, yaitu islamisasi sebagian dan islamisasi total.

Dalam pemahaman manajemen ekonomi syariah secara metodologi, dapat diklasifikasikan dan harus ada dari setiap faktornya yang meliputi leadership atau jiwa kepemimpinan, attitude atau sikap, dan communication atau komunikasi. Hal ini harus ada dalam manajemen dan bersifat terbuka serta demokratis.

\section{Konsep Bisnis dalam Pandangan Islam}

Semua manusia terlibat dalam kegiatan bisnis karena melalui bisnis ini manusia dapat memperoleh penghasilan, memenuhi kebutuhan akan barang dan jasa. Dunia bisnis bersifat dinamis, selalu bergerak maju, banyak inisiatif, kreatif, dan memberikan tantangan dalam menghadapi masa depan dengan penuh rasa optimis. Mobilitasnya tinggi, mereka bergerak dari satu daerah ke daerah lain, sesuai dengan musim, sesuai dengan situasi dan waktu yang tepat di satu daerah di mana orang membutuhkan barang. Kegiatan bisnis antara lain menyediakan barang pada waktu yang tepat, jumlah yang tepat, mutu yang tepat, dan harga yang tepat. ${ }^{4}$

Bisnis adalah pertukaran barang, jasa, atau yang saling menguntungkan atau memberikan manfaat. Menurut arti dasarnya, bisnis memiliki makna the buying and selling goods and services. Bisnis berlangsung karena adanya ketergantungan antar individu, adanya peluang internasional, usaha untuk mempertahankan dan meningkatkan standar hidup, dan lain sebagainya. Bisnis juga dipahami dengan suatu kegiatan usaha antar individu yang terorganisasi atau melembaga untuk menghasilkan atau menjual barang atau jasa guna mendapatkan keuntungan dalam memenuhi kebutuhan masyarakat. ${ }^{5}$

Agama Islam mewajibkan setiap manusia bekerja guna memenuhi kebutuhan hidupnya. Al-Quran menjelaskan tentang konsep bisnis dalam beberapa kata di antaranya al-tijärah (berdagang atau berniaga), al-bay' (menjual) dan 'an tadāyantum (muamalah). ${ }^{6}$ Bisnis dalam al-Quran mempunyai visi masa depan yang tidak semata-mata mencari keuntungan sesaat, melainkan mencari keuntungan yang hakiki. Islam memberikan batasan-batasan dan prinsipprinsip kepada umatnya dalam berbisnis yang harus ditaati. Beberapa prinsip yang harus

\footnotetext{
${ }^{4}$ Buchari Alma dan Donni Juni Priansa, Manajemen Bisnis Syariah (Bandung: Alfabeta, 2009), 124.

${ }^{5}$ Ika Yunia Fauzia, Etika Bisnis Islam (Jakarta: Kencaa Prenada Media Grup, 2013), 2.

${ }^{6}$ Ibid.
} 
dijalankan dalam praktik bisnis Islam di antaranya adalah:

1. Halal. Hal utama yang harus diperhatikan adalah halal. Allah memerintahkan kepada umatnya untuk mencari rezeki yang halal sesuai dalam Q.S. al-Baqarah ayat 275, yaitu Allah telah menghalalkan jual beli dan mengaharmkan riba. Jika diamati selama ini, maka sangat sulit untuk melihat bisnis yang tanpa melibatkan pinjaman bank yang mengandung riba. Bahkan bisa dikatakan, kebanyakan bisnis sekarang ini khususnya yang berskala besar tidak bisa beroperasi tanpa pinjaman bank.

2. Tayyib. Selain mewajibkan bisnis yang halal, Islam juga mengutamakan bisnis yang tayyibah, yaitu sesuatu yang baik dan memberikan manfaat tidak hanya bagi diri sendiri tetapi juga mitra bisnis dan masyarakat luas. Hal ini sesuai dengan firman Allah dalam Q.S. al-Nahl ayat 97.

3. Kejujuran. Agar tidak merugikan mitra transaksi atau pelanggan, maka Islam mengutamakan kejujuran. Bersikap jujur adalah salah satu kunci kesuksesan dalam menjalankan bisnis. Jujur merupakan salah satu sifat utama dan etika Islam yang luhur.

4. Kewajaran. Bisnis harus dijalankan secara wajar (fair) salah satu bentuk kewajaran dalam bisnis adalah dalam mengambil keuntungan. Produsen boleh mengambil keuntungan, perantara boleh menikmati keuntungan dan pengecer boleh memperoleh laba. Akan tetapi keuntungan terssebut seharusnya dalam porsi wajar. ${ }^{7}$

5. Seimbang. Berbisnis menurut ajaran Islam haruslah dilakukan untuk menjaga keseimbangan dan keselarasan dengan alam raya serta memakmurkan bumi. Hal tersebut sesuai dengan firman Allah dalam Q.S. Huud ayat 61.

6. Bersaing secara sehat. Bersaing dalam bisnis bukanlah sesuatu yang dilarang. Bersaing boleh dilakukan asalkan dilakukan secara fair dan sehat dalam rangka mencari berkah Allah.

7. Etos kerja. Islam adalah agama amal (kerja) baik untuk kepentingan hidup di dunia maupun kehidupan di akhirat. Islam memerintahkan para penganutnya untuk memiliki etos kerja yang tinggi. Etos kerja ini ditambah dengan profesionalisme.

8. Profesional. Profesional adalah sebutan bagi orang yang ahli dalam bidang tertentu yang dipelajari secara khusus. Dalam dunia bisnis, kata ini digunakan untuk menandakan kualitas pengerjaan atau jasa yang tinggi. Profesionalisme berarti komitmen terhadap klien, mitra bisnis, dan komunitas.

\section{Prinsip-Prinsip Manajemen Ekonomi Syariah}

Hakikat manajemen yang terkandung dalam al-Quran adalah merenungkan dan memandang ke depan suatu urusan (persoalan) agar dapat terpecahkan serta menimbulkan sebab-akibat. Maka hal tersebut mengakibatkan adanya prinsip-prinsip manajemen islami yang meliputi:

1. Keadilan

Keadilan merupakan satu prinsip fundamental dalam ideologi Islam. Pengelolaan keadilan seharusnya tidak sepotong-potong, tanpa mengacu kepada status sosial, kelas, dan keyakinan religius sseorang. Al-Quran telah memerintahkan kepada penganutnya

\footnotetext{
${ }^{7}$ Asyraf Muhammad Dawwabah, Meneladani Keunggulan bisnis Rasulullah (Semarang: Pustaka Nun, 2007),
} 58-59. 
untuk mengambil keputusan dengan berpegang pada kesamaan derajat, keutuhan, dan keterbukaan. Maka, keadilan adalah ideal untuk diterapkan dalam hubungan dengan sesama manusia. Kata kunci yang digunakan al-Quran dalam menjelaskan konsep keadilan adalah 'adl dan qist. 'Adl mengandung makna pemerataan dan kesamaan. Qist mengandung makna distribusi, angsuran, jarak yang merata. Keadilan yakni 'adl dan qist yang mengandung makna distribusi yang merata, termasuk distribusi materi. Keadilan terkandung dalam al-Quran juga bermakna menempatkan sesuatu pada proporsinya. ${ }^{8}$

2. Amanah dan bertanggung jawab

Amanah berarti memiliki tanggung jawab dalam melaksanakan setiap tugas dan kewajiban. Amanah ditampilkan dalam keterbukaan kejujuran, pelayanan yang optimal, dan iḥān (berbuat yang terbaik) dalam segala hal. Prinsip amanah dan bertanggung jawab bermakna bahwa setiap pribadi yang mmepunyai kedudukan fungsional dalam interaksi antara manusia dituntut agar melaksanakan kewajibannya dengan sebaikbaiknya. Apabila ada kelalaian terhadap kewajibannya akan mengakibatkan kerugian bagi diri sendiri. Berkenan dengan kewajiban yang menjadi tanggung jawab. Amanah dari Tuhan berupa tugas-tugas yang dibebankan oleh agama, amanah dari sesama manusia, baik amanah yang bersifat individual maupun organisasional, dan amanah untuk profesional. Seorang pebisnis haruslah memiliki sifat amanah, karena Allah menyebutkan sifat orang mukmin yang beruntung adalah dapat memelihara amanah yang diberikan kepadanya. ${ }^{9}$

3. Komunikatif

Dalam manajemen, komunikasi merupakan faktor terpenting dalam pelaksanan manajerial menuju tujuan yang diharapkan. Komunikasi harus disampaikan secara tepat. Ketepatan dalam penyampaian komunikasi tersebut disebut dengan komunikatif. Komunikatif dapat berarti tabligh yang berarti mengajak sekaligus memberikan contoh kepada pihak lain untuk melaksanakan ketentuan-ketentuan ajaran Islam dalam kehidupan sehari-hari. Orang yang memiliki sifat tabligh, akan menyampaikan informasi dengan benar dan dengan tutur kata yang tepat. Jika merupakan seorang pemimpin dalam dunia bisnis, ia haruslah menjadi seorang yang mampu mengkomunikasikan visi dan misinya dengan benar kepada karyawan dan stakeholder lainnya. Selain harus bi alhikmah dan penyampaian yang baik, seorang pemimpin harus mampu berargumentasi, berdiskusi dengan baik. ${ }^{10}$

\section{Fungsi Produksi dalam Manajemen Ekonomi Syariah}

Produksi merupakan urat nadi dalam kegiatan ekonomi. Dalam kehidupan ekonomi, tidak akan pernah ada kegiatan konsumsi, distribusi, ataupun pedagangan barang dan jasa tanpa diawali oleh produksi. Secara umum produksi merupakan suatu proses peningkatan utility (nilai) suatu benda. Dalam istilah ekonomi, produksi merupakan suatu proses atau

\footnotetext{
${ }^{8}$ Muhammad, Manajemen Dana Bank Syariah (Yogyakarta: Ekonisia, 2005), 72.

${ }^{9}$ Ibid., 73-74.

${ }^{10}$ Ibid., 134.
} 
siklus kegiatan-kegiatan ekonomi untuk menghasilkan barang dan jasa tertentu dengan memanfaatkan faktor-faktor produksi (amal/kerja, modal, tanah) dalam waktu tertentu. ${ }^{11}$

Dalam kegiatan menambah nilai guna barang atau jasa ini, dikenal lima jenis kegunaan. Pertama, guna bentuk adalah di dalam melakukan proses produksi. Kegiatannya adalah mengubah bentuk suatu barang sehingga barang tersebut mempunyai nilai ekonomis. Kedua, guna jasa adalah kegiatan produksi yang memberikan pelayanan jasa. Ketiga, guna tempat adalah kegiatan produksi yang memanfaatkan tempat-tempat di mana suatu barang memiliki nilai ekonomis. Keempat, guna waktu adalah kegiatan produksi yang memanfaatkan waktu tertentu. Kelima, guna milik adalah kegiatan produksi yang memanfaatkan modal yang dimiliki untuk dikelola orang lain dan dari produksi tersebut ia mendapatkan keuntungan. ${ }^{12}$

Produksi barang didasarkan atas gerak permintaan konsumen dan pada umumnya produsen selalu berupaya untuk mendapatkan keuntungan yang sebesar-besarnya. Namun apabila aktivitas produsen dipengaruhi semangat ruh Islam, maka aktivitasnya dalam memproduksi barang serta mencari keuntungan akan selalu disesuaikan dengan norma-norma yang berlaku dalam Islam. ${ }^{13}$

Adapun nilai-nilai yang penting dalam bidang produksi adalah pertama, ihsān dan itqān (sungguh-sungguh) dalam berusaha. Islam tidak hanya memerintahkan manusia untuk bekerja dan mengembangkan hasil usahanya, tetapi Islam memandang setiap usaha seseorang sebagai ibadah kepada Allah. Kedua, iman, takwa, mașlahah, dan istiqämah yang merupakan pendorong yang sangat kuat untuk membesar produksi melalui kerja keras dengan baik, ikhlas, dan jujur dalam melakukan kegiatan produksi yang dibutuhkan untuk kepentingan umat, agama, dan dunia. Sebagai implikasi iman, seorang mukmin tidak merasa cukup dengan melakukan pekerjaan hanya sekedarnya saja tetapi ia akan melakukan dengan sungguhsungguh. Mengarahkan segala kemampuannya untuk kebaikan adalah perintah Allah untuk mengawasi semua aktivitasnya dalam setiap situasi dan kondisi. ${ }^{14}$

Ketiga, al-șalah (baik dan bermanfaat). Islam hanya memerintahkan atau menganjurkan pekerjaan yang baik dan bermanfaat bagi dirinya sendiri maupun untuk orang lain. Agar setiap pekerjaan yang telah dilakukan senantiasa mampu memberi nilai tambah dan mengangkat derajat manusia baik secara individu maupun kelompok. Kelima, mencermati nilai waktu. Keuntungan maupun kerugian manusia banyak ditentukan oleh sikapnya terhadap waktu. Waktu adalah sumpah Allah dalam beberapa kitab suci-Nya yang mengakitkannya dengan nasib baik atau buruk yang akan menimpa manusia akibat tingkah lakunya sendiri. ${ }^{15}$

Selain itu prinsip etika dalam produksi yang wajib dilaksanakan oleh setiap muslim, baik individu maupun berkelompok adalah berpegang pada semua yang dihalalkan Allah dan tidak melewati batas. Konsep nilai halal haram tersebut akan diterapkan dalam memproduksi suatu barang agar tidak merugikan para konsumen yang memakai produk yang telah diproduksi. Konsep halal haram tersebut memiliki kriteria sebagai berikut:

\section{Halalan tayyiban}

Halalan tayyiban adalah kriteria halal dalam makanan, minuman, obat, dan alat

\footnotetext{
${ }^{11}$ Sa'id Sa'ad Marthon, Ekonomi Islam di Tengah krisis Ekonomi Global (Jakarta: Zikrul Hakim, 2007$), 47$.

${ }^{12}$ Nur Arianto Al Arif dan Euis Amalia, Teori Mikro Ekonomi (Jakarta: Kencana, 2010), 149-150.

${ }^{13}$ Abdul Aziz dan Mariyah Ulfah, Kapita Sengketa Ekonomi Islam Kontemporer (Bandung: Alfabeta, 2011$), 53$.

${ }^{14}$ Rozalinda, Ekonomi Islam Teori dan Aplikasinya pada Aktivitas Ekonomi (Jakarta: Rajawali Pers, 2014 ), 127.

${ }^{15}$ Abdul Aziz dan Mariyah Ulfah, Kapita Sengketa Ekonomi, 54.
} 
kosmetika.

2. Tidak mengandung unsur bahaya (darär)

Darär bentuk jamaknya adalah sempit atau penyakit yang melemahkan semangat juang atau semangat lainnya. Bahaya (darār) terbagi menjadi beberapa macam. Pertama, berdasarkan tempatnya, bahaya itu terbagi menjadi lima. Semuanya disebut dengan lima prinsip yang selalu dipelihara oleh setiap syariat di antaranya bahaya pada agama, bahaya pada jiwa, bahaya pada keturunan, bahaya pada harya, dan bahaya pada akal. Kedua, berdasarkan materi yang dikandungnya, bahaya itu terbagi menjadi dua, yaitu bahaya yang cepat dan bahaya yang lambat. Bahaya yang cepat adalah bahaya yang dengan segera dapat membinasakan orang yang mengkonsumsinya. Sedangkan bahaya yang lambat adalah bahaya yang timbul membutuhkan waktu jangka panjang bagi orang yang mengkonsumsinya.

Ketiga, berdasarkan kekuatan orang dalam mejalaninya, bahaya itu terbagi menjadi dua, yaitu bahaya yang mutlak dan bahaya yang nisbi. Bahaya yang mutlak adalah bahaya yang dialami oleh semua orang tanpa adanya pengecualian, berupa sesuatu yang membahayakan sebagian orang. Keempat, berdasarkan sifatnya, bahaya itu terbagi menjadi dua, yaitu bahaya yang bersifat indrawi dan bahaya yang bersifat maknawi. Bahaya yang bersifa maknawi adalah bahaya yang terjadi pada agama.

3. Tidak mengandung unsur iskär (memabukkan)

Iskär (memabukkan) pada salah satu kriteria yang menentukan keharaman, baik terdapat pada minum-minuman yang bersifat cairan, seperti khamr dan nabidz yang memabukkan, atau pada benda-benda padat seperti narkotika dan pada zat-zat adiktif lainnya. Setiap yang memabukkan apapun jenisnya, cair atau padat, mentah atau matang, berasal dari perasaan anggur bahka bahkan bahan lainnya adalah haram. ${ }^{16}$

Di kalangan para ekonomi Islam belum ada kesepakatan tentang faktor-faktor produksi. Karena baik dalam al-Quran maupun hadis tidak menjelaskan secara rinci. Di sisi lain karena kekayaan intelektual atau pemikiran ekonomi Islam telah dibangun secara bersama oleh dua kelompok intelektual, yaitu ahli hukum Islam yang menggunakan pendekatan normatif deduktif dan ahli ekonomi yang menggunakan pendekatan empiris deduktif. ${ }^{17}$ Namun secara umum, faktor produksi terdiri dari lima macam, yaitu:

1. Faktor alam

Faktor alam merupakan faktor yang mendasar dalam produksi. Alam yang dimaksud di sini adalah bumi dan segala isinya, baik yang berada di atas permukaan bumi maupun yang terkandung dalam perut bumi yang paling dalam sekalipun. Apa yang ada di bumi ini, seperti air, udara, sungai, tumbuh-tumbuhan, hewan, matahari, serta bulan dianjurkan bahkan diperintahkan kepada manusia untuk memelihara dan memanfaatkannya dengan baik. Hal ini sesuai dengan firman Allah dalam Q.S. alSajadah ayat 27. Selain kekayaan alam yang berada di atas permukaan bumi, al-Quran juga menganjurkan manusia untuk memanfaatkan kekayaan yang berada di dasar bumi, seperti emas, tembaga, perak, dan barang tambang lainnya sesuai dengam firman Allah

\footnotetext{
${ }^{16}$ Ali Mustafa Yaqub, Kriteria Halal-Haram untuk Pangan, Obat, dan Kosmetika Menurut Al-Quran dan Hadist (Jakarta: PT Pustaka Firdaus, 2013), 12.

${ }^{17}$ Sa'id Sa'ad Marthon, Ekonomi Islam, 65.
} 
dalam Q.S. al-Hadid ayat 25.

2. Tenaga kerja terkait langsung dengan tuntutan hak milik melalui produksi.

Tenaga kerja merupakan faktor pendayaguna dari faktor produksi sebelumnya. Oleh karena sistem ekonomi Islam merupakan sistem ekonomi yang integral, maka faktor tenaga kerja pun mendapatkan perhatian dalam sistem ekonomi Islam. Dalam perspektif ekonomi Islam, diskursus tentang tenaga kerja ini bermuara sekitar hakikat bekerja, kewajiban bekerja, kewajiban pekerja, dan hak pekerja. Islam memerintahkan buruh atau pegawai untuk melaksanakan tugas dengan mencurahkan kemampuan terbaiknya, bekerja seoptimal mungkin, dan sebaliknya Islam mendesak para pengusaha untuk membayar upah atau gaji secara adil, tepat waktu, dan tidak mengeksploitasi para pekerjanya. ${ }^{18}$ Bekerja merupakan salah satu amalan yang dipandang sebaga bentuk ibadah kepada Allah. Memenuhi kebutuhan hidup keluarga, istri dan anak merupakan sebuah kewajiban dengan merealisasikan kewajiban ini berarti telah beribadah kepada Allah. Dengan demikian bekerja yang diniatkan untuk melaksanakan perintah Allah maka bekerja tersebut dikategorikan ibadah.

3. Modal

Modal juga terlibat langsung dalam kegiatan manajemen produksi. Karena pengertian modal mencakup modal produktif yang mengahasilkan barang-barang yang dikonsumsi, dan modal individu yang dapat menghasilkan kepada pemiliknya. Modal diartikan dengan kekayaan yang memberikan penghasilan kepada pemiliknya.

4. Manajemen

Manajemen dalam perspektif Islam merupakan landasan yang menentukan keberhasilan sebuah kegiatan ekonomi. Dengan manajemen, pelaku ekonomi dapat memperhitungkan keuntungan yang diperoleh dan resiko kerugian yang mungkin akan dihadapi di kemudian hari.

5. Teknologi

Dengan berkembangnya zaman, teknologi semakin menghasilkan inovasi dan kreatifitas baru sehingga dapat memanfaatkan alam bagi kesejahteraan dan kenyamanan manusia. Dengan teknologi yang semakin maju dan canggih ini segala kegiatan produksi akan terasa lebih ringan, cepat dan praktis.

Manajemen produksi merupakan suatu ilmu yang membahas secara kompeherensif bagaimana pihak manajemen produksi menggunakan ilmu dan seni yang dimiliki dengan mengarahkan dan mengatur orang-orang untuk mencapai suatu hasil produksi yang diinginkan. Penekanan pada kata seni, menunjukkan bahwa suatu pekerjaan yang dilakukan dengan mempergunakan orang lain tidak akan mudah dikerjakan dan diselesaikan jika semua itu dilakukan tidak dengan pendekatan seni namun misalnya dengan mengandalkan kekuasaan semata. ${ }^{19}$

Dalam manajemen, produksi merupakan suatu proses perencanaan, pengorganisasian, pengarahan, dan pengendalian kegiatan produksi. Tujuan dari manajemen produksi adalah untuk menghasilkan layanan barang dengan kualitas dan kuantitas yang tepat pada waktu dan biaya yang tepat juga. Kualitas produk ini ditetapkan berdasakan apa yang dibutuhkan

\footnotetext{
${ }^{18}$ Buchari Alma dan Donni Juni Priansa, Manajemen Bisnis Syariah, 191.

${ }^{19}$ Irham Fahmi, Manajemen Produksi dan Operasi (Bandung: CV Alfabeta, 2012), 3.
} 
pelanggan saat ini. Kualitas produk yang tepat belum tentu dapat menciptakan kualitas terbaik. Dikarenakan hal ini ditentukan oleh biaya produk yang telah dikeluarkan dan karakteristik dari setiap produk yang sesuai dengan persyaratan spesifik.

Dalam menghasilkan suatu produk, harus diperhatikan beberapa aspek. Salah satunya yaitu ketepatan dalam jumlah produksi. Karena, apabila produk yang dikeluarkan melebihi permintaan maka modal akan ditutup dalam bentuk inventaris, dan jika kuantitas yang diproduksi di bawah permintaan, maka akan menyebabkan kekurangan produk.

Pelaksanaan implementasi fungsi produksi dalam manajemen ekonomi syariah diperlukan perencanaan, pengorganisasian, pengarahan, dan pengendalian yang dilakukan agar tujuan yang dikehendaki dapat tercapai. Manajemen produksi berfungsi dalam pengambilan keputusan sehingga dapat tepat sasaran berupa tepat waktu, tepat mutu, dan tepat jumlah dengan biaya yang efisien.

Selain itu, memproduksi suatu barang juga memiliki standar produk demi tercapainya peningkatan mutu kehidupan, menjaga standar produk sambil mengedepankan prinsip halal, bersih, dan baik adalah tuntutan etika bisnis islami. Apabila memproduksi pakaian, maka pakaian itu dibuat dari bahan yang tidak haram, dari bahan yang tidak membuat madărat bagi tubuh (tidak meenyebabkan rasa gatal dan sebagainya). Apabila yang diproduksi adalah produk untuk dimakan atau diminum, termasuk obat-obatan, maka syarat utamanya yaitu harus dibuat dari bahan-bahan yang halal.

Untuk terwujudnya kemaslahatan individu maupun kelompok, sistem ekonomi Islam menyediakan beberapa landasan teoritis, yaitu keadilan ekonomi, jaminan sosial, pemanfaatan sumber daya ekonomi produktif secara efisien. Selain itu, produksi dalam pandangan Islam dipandang sebagai bagian dari ibadah dan kita dianjurkan untuk melakukan amal ibadah sebanyak-banyaknya. ${ }^{20}$

\section{Fungsi Personalia dalam Manajemen Ekonomi Syariah}

Edwin B. Flippo menjelaskan tentang fungsi-fungsi manajemen personalia. Pertama, pengadaan tenaga kerja. Fungsi operasional pertama dari manajemen personalia adalah berupa usaha untuk memperoleh jenis dan jumlah yang tepat dari personalia yang diperlukan untuk menyelesaikan sasaran organisasi. Hal-hal yang dilakukan dalam kaitan ini adalah penentuan sumber daya manusia yang diperlukan dan perekrutannya, seleksi, dan penempatan. Kedua, pengembangan tenaga kerja. Setelah personalia diperoleh, mereka harus dikembangkan sampai pada tingkat tertentu. Pengembangan merupakan peningkatan keterampilan melalui pelatihan yang perlu untuk prestasi kerja yang tepat. Ketiga, kompensasi (imbalan) tenaga kerja. Fungsi ini dirumuskan sebagai balas jasa yang layak kepada personalia untuk sumbangan mereka kepada tujuan organisasi. Struktur kompensasi meliputi gaji pokok, tunjangan keluarga, tunjangan makan, tunjangan transportrasi, tunjangan kehadiran, dan tunjangan jabatan.

Keempat, integrasi (penyatuan) tenaga kerja. Setelah karyawan diperoleh, dikembangkan dan diberi kompensasi yang layak, maka selanjutnya adalah integrasi. Integrasi merupakan suatu usaha untuk menghasilkan suatu kecocokan yang layak atas kepentingankepentingan perorangan, masyarakat, dan organisasi. Kelima, pemeliharaan tenaga kerja. Jika

\footnotetext{
${ }^{20}$ Djaslim Saladin, Konsep Dasar Ekonomi dan Lembaga Keuangan Islam (Bandung: Linda Karya, 2000), 23.
} 
kita telah melaksanakan fungsi-fungsi di atas dengan baik, maka yang tidak kalah pentingnya adalah pemeliharaan pegawai. Pemeliharaan merupakan usaha untuk meningkatkan kemauan dan kemampuan untuk bekerja para pegawai. Keenam, pemutusan hubungan kerja, fungsi terakhir dari manajemen personalia adalah pemutusan hubungan kerja dan mengembalikan para pekerja kepada masyarakat. Sebagian besar karyawan tidak meninggal dunia pada masa kerjanya, organisasi bertanggung jawab untuk melaksanakan proses pemutusan hubungan kerja sesuai dengan persyaratan-persyaratan yang telah ditentukan dan menjamin bahwa warga masyarakat yang dikembalikan itu berada dalam keadaan yang sebaik mungkin. ${ }^{21}$

Manajemen personalia ialah manajemen yang memperhatikan orang-orang dalam organisasi. Perhatian terhadap orang-orang ini cukup merekrut, menempatkan, melatih, mengembangkan, dan meningkatkan kesejahteraan mereka yang dikatakan sebagai fungsi manajemen personalia. ${ }^{22}$ Menurut Ngalim Purwanto, personalia dalam suatu organisasi harus memiliki prinsip-prinsip memiliki tujuan yang jelas; tiap anggota dapat memahami dan menerima tujuan tersebut; adanya kesatuan arah sehingga dapat menimbulkan kesatuan tindak dan kesatuan pikiran; adanya kesatuan perintah; adanya keseimbangan antara wewenang dan tanggung jawab masing-masing anggota; adanya pembagian tugas atau pekerjaan sesuai dengan kemampuan, keahlian dan bakat masing-masing sehingga dapat menimbulkan kerjasama yang harmonis; adanya jaminan keamanan dalam bekerja; adanya gaji yang setimpal dengan jasa atau pekerjaan; garis-garis, kekuasaan dan tanggung jawab serta tata kerjanya jelas tergambar dalam struktur organisasi. ${ }^{23}$

Sebuah bisnis atau usaha ekonomi tidak akan pernah lepas dari tenaga kerja. Tenaga kerja dalam hal ini mencakup tenaga kerja profesional yang amat tinggi dari jenis apapun juga, hingga tenaga kerja yang tidak memiliki skill. Jadi istilah tenaga kerja mencakup ilmuan, dokter, insinyur, ahli ekonomi, guru besar, ahli hukum serta pekerja-pekerja biasa di pabrik-pabrik, sawah dan perkantoran. ${ }^{24}$

Fungsi personalia yang berkaitan dengan sumber daya manusia meliputi empat aspek, yaitu seleksi; penempatan dan pembagian tugas dan tanggung jawab; pemberian imbalan, hubungan kerja; dan penilaian, pengembangan, penilaian prestasi kerja. Dalam impementasi fungsi personalia dalam manajemen ekonomi syariah tidak hanya personalia yang perlu dibina atau dikembangkan, melainkan perusahaan atau instansinya juga perlu dibina dan dikembangkan. Tujuan pengembangan baik melalui personalia maupun melalui individu ialah memperbaiki performance organisasi dengan menciptakan iklim sumber daya manusia yang positif. Agar proses pengembangn para personalia berjalan dengan lancar dan kontinyu, maka dibutuhkan kepemimpinan yang memperlakukan mereka sesuai dengan bakat, kemampuan, dan minat masing-masing individu.

\section{Fungsi Pemasaran dalam Manajemen Ekonomi Syariah}

Manajemen dalam pemasaran bisnis merupakan alat analisis, perencanaan, penerapan, dan pengendalian program yang dirancang untuk menciptakan, membangun, dan

\footnotetext{
${ }^{21}$ Flippo, Manajemen Personalia (Jakarta: Erlangga, 1984), 5.

${ }^{22}$ Made Pidarta, Manajemen Pendidikan Indonesia (Jakarta: Rineka Cipta, 2011), 112.

${ }^{23}$ Ngalim Purwanto, Administrasi dan Supervisi Pendidikan (Bandung: Remaja Rosdakarya, 1991), 17-18.

${ }^{24}$ Muhammad Syarif Chaudry, Sistem Ekonomi Islam: Prinsip Dasar (Jakarta: Kencana, 2012), 185.
} 
mempertahankan pertukaran yang menguntungkan dengan target pasar. Sasaran dengan maksud untuk mencapai tujuan utama dalam bisnis, yaitu mendapatkan keuntungan atau laba. Dalam bisnis, konsep utama pemasaran bertujuan untuk memberikan kepuasan terhadap keinginan dan kebutuhan pembeli atau konsumen. Terdapat beberapa elemen penting dalam manajemen pemasaran, yaitu antara lain:

\section{Market oriented}

Berorientasi pada keinginan konsumen di mana akan menjadikan konsumen sebagai raja, produsen akan memberikan berbagai penawaran baik itu mulai dari produk sampai pelayanan konsumen.

2. Perencanaan pemasaran

Penyusunan kegiatan pemasaran secara terpadu. Seluruh aktivitas pemasaran mulai dari strategi, implementasi, analisis, pengawasan serta aktivitas lainnya yang berhubungan dengan pemasaran harus disusun secara terperinci.

3. Kepuasan konsumen

Pencapaian tingkat kepuasan konsumen tidak hanya diukur dari kualitas produk saja, namun juga dilihat bagaimana strategi pemasaran dari perusahaan dilakukan.

Keberhasilan usaha suatu perusahaan ditentukan oleh keberhasilan pemasarannya. Pemasaran merupakan suatu proses kegiatan yang mulai jauh sebelum barang-barang atau bahan-bahan masuk dalam produksi. Fungsi Pemasaran berperan sebagai sarana perusahaan untuk dapat memenuhi kebutuhan customer yang tepat melalui produk dan jasa yang ditawarkan perusahaan. Tujuan fungsi pemasaran adalah untuk mengetahui dan memahami customer sedemikian rupa sehingga produk atau jasa yang ditawarkan perusahaan cocok dengan pelanggan. ${ }^{25}$

Pemasaran yang berhasil pasti memiliki konsep yang baik, tidak ada unsur penipuan maupun ketidakjujuran, biasanya pemasaran seperti ini menggunakan konsep religius atau memasukkan unsur-unsur keagamaan sehingga ada kehati-hatian dalam memasarkannya. Fungsi pemasaran terdapat beberapa faktor yang saling berintegrasi dan bergantung satu sama lain. Fungsi-fungsi pemasaran meliputi fungsi pertukaran, fungsi pengadaan, dan fungsi pemberian jasa.

Impelementasi pemasaran dalam manajemen ekonomi syariah adalah suatu proses untuk mengubah strategi dan rencana pemasaran menjadi tindakan pemasaran untuk mencapai sasaran. Impementasi mencakup aktifitas sehari-hari dari bulan ke bulan yang secara efektif melaksanakan rencana pemasaran. Agar impelementasi pemasaran tersebut bisa terarah, maka rencana pemasaran harus ditentukan secara baik. Keberhasilan implementasi banyak ditentukan oleh adanya kemampuan mengkomunikasikan secara efektif langkah demi langkah yang dibutuhkan dalam pelaksanaan.

\section{Fungsi Keuangan dalam Manajemen Ekonomi Syariah}

Manajemen keuangan adalah suatu proses dalam pengaturan aktivitas atau kegiatan dalam suatu organisasi, dimana didalamnya termasuk kegiatan perencanaan, analisis, dan pengendalian terhadap kegiatan keuangan. Secara umum kegiatan utama atau fungsi keuangan terbagi menjadi dua kelompok, yaitu kegiatan mencari dana dan kegiatan menggunakan dana.

\footnotetext{
${ }^{25}$ Philip Kotler dan Kevin L. Keller, Manajemen Pemasaran (Jakarta: PT Macanan Jaya Cemerlang, 2009$), 7$.
} 
Manajemen syariah adalah kegiatan manajerial keuangan untuk mencapai tujuan dengan memperhatikan kesesuaiannya pada prinsip-prinsip syariah. Najmudin mengemukakan bahwa manajemen keuangan adalah keseluruhan keputusan dan aktivitas yang menyangkut usaha untuk memperoleh dana dan mengalokasikan dana tersebut berdasarkan perencanaan, analisis, dan pengendalian sesuai dengan prinsip manajemen bahwa upaya memperoleh dan mengalokasikan dana harus mempertimbangkan efisiensi (daya guna) dan efektivitas (hasil guna). ${ }^{26}$

Manajemen keuangan syariah adalah semua aktivitas yang menyangkut usaha untuk memperoleh dana dan mengalokasikannya berdasarkan perencanaan, analisis dan pengendalian sesuai dengan prinsip manajemen dan berdasarkan prinsip syariah. ${ }^{27}$ Sedangkan keuangan syariah sendiri adalah bentuk keuangan yang didasarkan pada syariah atau bangunan hukum Islam. Syariah, berarti jalan menuju sumber air, dipenuhi dengan tujuan moral dan pelajaran tentang kebenaran. Karena itu, syariah lebih dari sekedar seperangkat aturan-aturan hukum. ${ }^{28}$ Tujuan ekonomi syariah adalah kecukupan dan kedamaian yang bisa diwujudkan. Menjamin bahwa setiap kebutuhan dasar seseorang dipenuhi. Kebutuhan dasar tersebut mencakup makanan, rumah, layanan kesehatan, pendidikan, dan semua yang dianggap perlu sesuai dengan adat istiadat.

Dalam impelementasi pengelolaan manajemen keuangan terdapat dua unsur yang tidak bisa dipisahkan satu dengan lainnya, yaitu unsur pimpinan dan pengelolaan (bendahara). Unsur pimpinan disebut sebagai pihak yang mempunyai jabatan dan wewenang dalam menguasai anggaran untuk mengambil tindakan yang berkaitan dengan penerimaan dan pengeluaran. Sementara unsur bendahara adalah seseorang yang diberi tugas menerima semua pendapatan dan melakukan pengeluaran yang diperlukan oleh perusahaan sesuai izin dan perintah dari pimpinan.

Penerapan implementasi manajemen keuangan masih sering mengalami kegagalan karena banyak organisasi atau perusahaan yang dalam mengatur keuangannya bercirikan monolitik, prosedural, dana sebagai target, dan berorientasi hasil serta tidak mandiri. Pelaksanaan keuangan atau anggaran pada sebuah organisasi atau perusahaan di samping memerlukan tanggung jawab, juga dituntut adanya komitmen atas nilai-nilai moral, seperti kejujuran, terbuka, teliti, cermat, dan sabar.

\section{Kesimpulan}

Bisnis merupakan salah satu kegiatan yang terjadi dalam kehidupan manusia seharihari. Dalam menjalankan bisnis tersebut terdapat beberapa prinsip-prinsip yang harus dijalankan. Berdasarkan al-Quran dan hadis setiap transaksi ekonomi syariah dianggap benar apabila tidak ada wahyu yang melarang atau mengaturnya. Dunia bisnis merupakan interaksi antara berbagai tipe manusia di mana sangat berpotensi menjerumuskan para pelakunya ke dalam hal-hal yang diharamkan, baik karena didesak oleh kebutuhan ekonomi maupun dilakukan secara sendiri atau berkelompok dengan orang lain secara tidak sah atau karena

\footnotetext{
${ }^{26}$ Najmudin, Manajemen Keuangan dan Aktualisasi Syar'iyyah Modern (Yogyakarta: Andi, 2011), 39.

${ }^{27}$ Dadang Husen Soban, Manajemen Keuangan Syariah (Bandung: Pustaka Setia, 2017), 20.

${ }^{28}$ Ma'ruf Abdullah, Manajemen Bisnis Syariah (Yogyakarta: Aswaja Pressindo, 2014), 175.
} 
ketatnya persaingan yang membuat para pelaku bisnis melakukan hal-hal yang terlarang dalam agama.

Manajemen bisnis tidak boleh lepas dari keyakinan dan nilai yang mendasarinya. Manajemen harus sesuai dengan pandangan hidup dan Islam. Al-Quran telah memberikan petunjuk yang dapat digunakan sebagai dasar membangun ilmu manajemen bisnis Islam. Dalam pelaksanaan impementasi diperlukan dukungan dari berbagai pihak agar dapat terlaksana dengan baik termasuk dari pimpinan yang mempunyai jabatan paling tinggi dan karyawan atau buruh. Semua pihak harus saling bekerja sama dan saling tolong menolong, sehingga fungsi-fungsi dalam bisnis dapat diimplementasikan ke manajemen ekonomi syariah.

\section{Daftar Rujukan}

Abdullah, Ma'ruf. Manajemen Bisnis Syariah. Yogyakarta: Aswaja Pressindo, 2014. Al Arif, Nur Arianto dan Euis Amalia. Teori Mikro Ekonomi. Jakarta: Kencana, 2010.

Ash-shadr, Muhammad Baqir. Falsafatuna terhadap Berbagai Aturan Filsafat Dunia. Bandung: Mizan, 1999.

Aziz, Abdul dan Mariyah Ulfah. Kapita Sengketa Ekonomi Islam Kontemporer. Bandung: Alfabeta, 2011.

Buchari, Alma dan Donni Juni Priansa. Manajemen Bisnis Syariah. Bandung: Alfabeta, 2009. Chaudry, Muhammad Syarif. Sistem Ekonomi Islam: Prinsip Dasar. Jakarta: Kencana, 2012.

Dawwabah, Asyraf Muhammad. Meneladani Keunggulan Bisnis Rasulullah. Semarang: Pustaka Nuun, 2007.

Fahmi, Irham. Manajemen Produksi dan Operasi. Bandung: CV Alfabeta, 2012.

Fauzia, Ika Yunia. Etika Bisnis Islam. Jakarta: Kencana Prenada Media Grup, 2013.

Flippo. Manajemen Personalia. Jakarta: Erlangga, 1984.

Kotler, Philip dan Kevin L. Keller. Manajemen Pemasaran. Jakarta: PT Macanan Jaya Cemerlang, 2009.

Marthon, Sa'id Sa'ad. Ekonomi Islam di Tengah Krisis Ekonomi Global. Jakarta: Zikrul Hakim, 2007.

Muhammad. Manajemen Dana Bank Syariah. Yogyakarta: Ekonisia, 2005.

Najmudin. Manajemen Keuangan dan Aktualisasi Syar'iyyah Modern. Yogyakarta: Andi, 2011.

Pidarta, Made. Manajemen Pendidikan Indonesia. Jakarta: Rineka Cipta, 2011.

Purwanto, Ngalim. Administrasi dan Supervisi Pendidikan. Bandung: Remaja Rosdakarya, 1991.

Rozalinda. Ekonomi Islam Teori dan Aplikasinya pada Aktivitas Ekonomi. Jakarta: Rajawali Pers, 2014.

Saladin, Djaslim. Konsep Dasar Ekonomi dan Lembaga Keuangan Islam. Bandung: Linda karya, 2000.

Soban, Dadang Husen. Manajemen Keuangan Syariah. Bandung: Pustaka Setia, 2017.

Syafi'i, Inu Kencana. Pengantar Ilmu Filsafat. Bandung: Refika Aditama, 2004.

Yaqub, Ali mustafa. Kriteria Halal Haram untuk Pangan, Obat, dan Kosmetika Menurut AlQur'an dan Hadist. Jakarta: PT Pustaka Firdaus, 2013. 